\title{
Simulasi Sistem Rantai Pasokan Studi Kasus Produk Telepon di PT XYZ dengan ProModel
}

\author{
Jeremia $^{1 *}$, Carlos Checa Putra Hardiyanto ${ }^{2}$, Sean Rennard Tirtawijaya ${ }^{3}$, \\ Christopher Kenny Yandra ${ }^{4}$, Alvin Maxwell ${ }^{5}$ \\ 1,2,3,4,5 Teknik Industri, Universitas Kristen Petra, Surabaya, Indonesia \\ (*jerueda2408@gmail.com)
}

\begin{abstract}
Abstrak - PT XYZ merupakan suatu industri manufaktur yang memproduksi satu jenis telepon dan melakukan pemenuhan permintaan kepada toko-toko atau konsumen yang ada. PT XYZ memiliki keinginan untuk mengoptimalkan sistem rantai pasokan dari telepon yang terdiri atas tiga pihak supplier, PT XYZ sendiri selaku pemilik gudang bahan baku, manufaktur, dan gudang barang jadi, serta satu pihak toko. Berdasarkan hal tersebut, dilakukan suatu simulasi dengan menggunakan komputer untuk menggambarkan kondisi sekarang dari PT XYZ. Simulasi akan membantu dan memudahkan perusahaan untuk memperbaiki maupun optimasi sistem rantai pasokan yang sudah ada di dalam perusahaan. Berdasarkan hal tersebut, maka disusun suatu model kondisi awal dan usulan, yang mana hasilnya dapat menaikkan utilitas manufaktur dari 52,53\% menjadi 77,46\%. Perusahaan bisa mempertimbangkan untuk tetap mempertahankan model awal dengan model usulan, dengan tetap memperhatikan penggunaan forklift untuk daerah Gudang Bahan Baku (GBB) dengan lebih efisien.
\end{abstract}

Kata kunci: pemodelan, ProModel; reorder point; simulasi; sistem rantai pasok

\section{PENDAHULUAN}

Simulasi merupakan suatu upaya meniru fitur, tampilan, dan karakteristik sebuah sistem nyata yang biasanya melalui sebuah model komputer. (Heinzer et al, 2017). Simulasi disini digunakan untuk menggambarkan sistem nyata dalam model untuk memudahkan penelitian lebih dalam dan melakukan perbaikan dari sistem nyata yang sudah ada. Hal ini dilakukan juga ke dalam suatu sistem rantai pasokan dari perusahaan manufaktur telepon di PT XYZ. PT XYZ merupakan suatu industri manufaktur yang memproduksi satu jenis telepon dan melakukan pemenuhan permintaan kepada toko-toko atau konsumen yang ada. Penelitian ini bertujuan untuk mengoptimalkan sistem rantai pasokan telepon milik PT XYZ yang terdiri atas tiga pihak supplier, PT XYZ sendiri selaku pemilik gudang bahan baku, manufaktur, dan gudang barang jadi, serta satu pihak toko.

Berdasarkan hal tersebut, dilakukan suatu simulasi dengan menggunakan komputer untuk menggambarkan kondisi sekarang dari PT XYZ. Simulasi akan membantu dan memudahkan perusahaan untuk memperbaiki maupun optimasi sistem rantai pasokan yang sudah ada di dalam perusahaan. Optimasi sendiri adalah kata yang diambil dari kata optimal, dimana menurut KBBI optimal adalah segala sesuatu yang paling menguntungkan. Maka dari itu, optimasi merupakan kegiatan untuk mendapatkan kondisi yang paling menguntungkan baik itu dalam hal maksimasi ataupun minimasi (Munirah \& Subanar, 2017). Optimasi sendiri sangat sering digunakan untuk mengoptimalkan banyak hal seperti contoh mengoptimalkan biaya produksi, lalu mengoptimalkan penjualan, hingga mengoptimalkan kinerja dari karyawan. Optimasi disini adalah untuk mengoptimalkan sistem dari rantai pasokan perusahaan agar menjadi lebih efisien dan menghasilkan output berupa waktu dan biaya yang lebih baik lagi. Simulasi dan optimasi pada penelitian ini akan dibantu dengan menggunakan software ProModel keluaran tahun 2011. ProModel sendiri merupakan sebuah software simulasi yang berbasis windows untuk melakukan suatu simulasi dan menganalisis suatu sistem (Cornellia, 2018).

Simulasi yang dilakukan pada penelitian ini terdiri atas 7 lokasi dengan 8 entitas dan 8 sumber daya. Lokasi terdiri atas supplier kabel, supplier badan telepon, supplier box, gudang bahan baku/GBB, manufaktur, gudang barang jadi/GBJ, dan toko. Entitas yang digunakan antara lain bahan baku kabel, badan telepon, dan box dengan kontainernya masing-masing serta entitas pesanan dan telepon itu sendiri. Resources atau sumber daya yang digunakan adalah forklift untuk GBB, truk untuk masing-masing bahan baku, dan forklift untuk setiap bahan baku yang ada. Batasan yang dalam penelitian ini antara lain Simulasi rantai pasokan dilakukan hanya untuk memenuhi demand dari satu toko, lalu data waktu yang digunakan didasarkan pada estimasi penulis dan bersifat konstan tanpa menggunakan random maupun distribusi acak. Demand dari toko menggunakan distribusi dan tidak memperhatikan faktor keterlambatan dalam transportasi baik itu pengiriman dari supplier ke perusahaan, maupun dari perusahaan ke toko. Pengujian dan kontrol kualitas diasumsikan baik dan tidak 
ada bahan baku serta produk jadi yang terkena reject serta tidak melakukan validasi terhadap model, hanya sampai pada verifikasi.

\section{STUDI LITERATUR}

\section{A. Simulasi \& Pemodelan}

Menurut Heizer, Render dan Munson (2017), simulasi merupakan suatu upaya meniru fitur, tampilan, dan karakteristik sebuah sistem nyata yang biasanya melalui sebuah model komputer. Simulasi adalah salah satu pendekatan kuantitatif yang paling banyak digunakan untuk pengambilan keputusan. Selain itu simulasi ini sendiri merupakan salah satu dari berbagai macam cara untuk memecahkan dan meniru proses nyata untuk dimodelkan atau digambarkan dalam suatu sistem, untuk menemukan dan menyelesaikan suatu permasalahan. Simulasi merupakan salah satu tools yang tepat untuk digunakan agar memudahkan dan lebih efisien dalam melakukan eksperimen mengingat biaya yang dikeluarkan bisa sangat mahal dan bisa saja memerlukan waktu yang lama dan mampu menggambarkan keadaan yang rumit sekalipun (Hamali, 2017).

Pemodelan merupakan proses untuk membuat sebuah model dari sistem. Model adalah representasi dari sebuah bentuk nyata, sedangkan sistem adalah saling keterhubungan antar elemen yang membangun sebuah kesatuan, biasanya dibangun untuk mencapai tujuan tertentu (Riswana, 2018). Tujuan suatu pemodelan adalah untuk menganalisa dan memberi prediksi yang dapat mendekati kenyataan sebelum sistem diterapkan di lapangan. Kesulitan untuk memprediksi dan mengamati proses tertentu pada lapangan akan menjadi persoalannya, dimana model dapat memformulasikan sebuah proses tertentu namun tidak memungkinkan untuk melakukan analisa untuk mendapatkan solusi tepat sehingga perlu dilakukan lagi perbandingan atau validasi antara pemodelan matematik dengan kondisi lapangan.

\section{B. ProModel}

ProModel merupakan salah satu software simulasi yang dapat berjalan di atas platform Windows untuk disimulasikan dan menganalisis sistem produksi dari seluruh tipe sistem dan ukuran (mengutip penjelasan dari website resmi ProModel - promodel.com). ProModel merupakan aplikasi simulasi yang biasanya digunakan untuk merencanakan, mendesain, dan meningkatkan sebuah manufaktur, logistik yang ada maupun baru. ProModel menyediakan kombinasi yang sempurna dari kemudahan, fleksibilitas. dan kemampuan untuk memodelkan semua situasi dan dengan kemampuan animasi yang hidup membuat simulasi semakin nyata. Tujuan yang bisa dicapai dari penggunaan ProModel yaitu untuk mendapatkan sistem yang optimal dari beberapa alternatif sistem yang telah direncanakan dan menghemat waktu serta biaya dibanding melakukan simulasi secara nyata (Trenggonowati, 2017).

\section{Reorder Point (ROP)}

Menurut Unsulangi, Jan, dan Tumewu (2019) mengutip Heizer dan Render, ROP merupakan titik pemesanan yang menunjukkan saat persediaan menyentuh titik tersebut pemesanan harus dilakukan. Dalam memperhitungkan ROP, harus mempertimbangkan variabel seperti lead time pemesanan barang dan safety stock. ROP yang terlalu rendah atau sedikit menyebabkan persediaan akan habis sebelum persediaan pengganti diterima, sehingga akan mengacaukan jalannya lantai produksi yang dapat mengakibatkan permintaan pelanggan gagal dipenuhi. Namun, jika titik pemesanan ulang terlalu tinggi, akan mengakibatkan pemborosan biaya dan investasi yang berlebih. Jika ROP terlambat atau terlalu sedikit akan muncul biaya kekurangan bahan (stock out cost), sedangkan titik ROP yang berjumlah terlalu banyak akan berakibat munculnya biaya tambahan seperti naiknya inventory cost hingga material handling cost (Lukmana \& Trivena, 2015).

\section{Uji T \& Uji Kecukupan Replikasi}

Uji T adalah salah satu uji statistik yang digunakan untuk menguji dan membuktikan benar salahnya suatu hipotesis untuk mengetahui kebenaran dari hipotesis yang diajukan dengan cara membedakan rata - rata dari dua populasi yang ada (Soeprajogo \& Ratnaningsih, 2020). Uji T pertama kali dikembangkan oleh William 
Sealy Gosset pada 1915. Uji T terdiri dari dua macam uji yaitu Uji T Berpasangan (Paired T-Test) dan Uji T Dua Sampel (Two Sample T-Test).

Uji kecukupan replikasi adalah uji yang dilakukan untuk mengetahui cukup tidaknya maupun mengetahui jumlah replikasi yang harus dilakukan untuk mereduksi variasi atau varian dari model yang ada (Sugiarto \& Buliali, 2012). Uji kecukupan replikasi dilakukan dengan menghitung nilai rata - rata, standar deviasi, penentuan error dan juga nilai tabel t. Nilai $\mathrm{N}$ harus lebih besar dibandingkan nilai $\mathrm{N}$ ' agar model yang dihasilkan memiliki varian yang tidak besar. Apabila varian tidak terlalu besar, maka model yang dihasilkan akan menjadi lebih baik dan tidak menyebabkan bias. Jika nilai N' lebih besar dibandingkan $\mathrm{N}\left(\mathrm{N}^{\prime}<\mathrm{N}^{\prime}\right)$, maka jumlah replikasi harus ditambahkan.

\section{METODOLOGI}

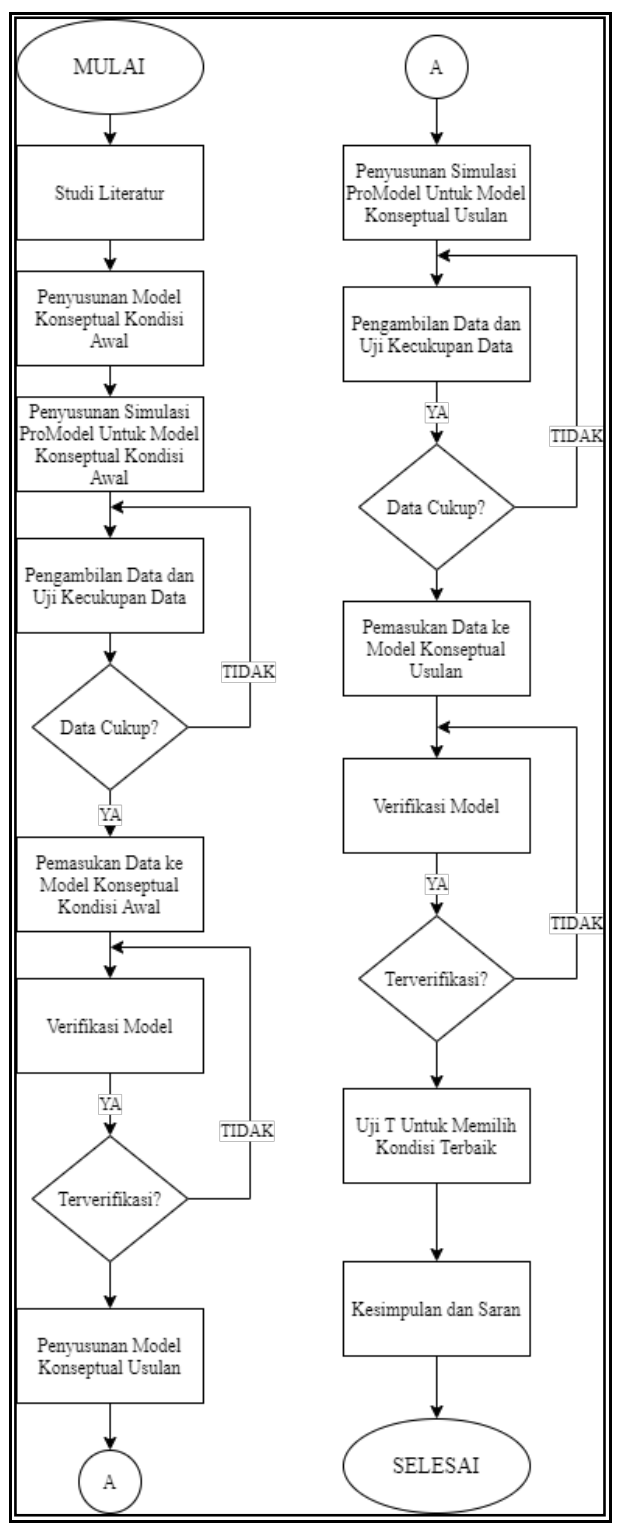

Gambar 1. Metodologi penelitian

Metodologi penelitian yang digunakan terdiri atas beberapa langkah seperti pada Gambar 1. Metodologi penelitian dimulai dari studi literatur untuk pencarian teori pendukung dari masalah yang ada, lalu penyusunan model konseptual berupa cerita pendek yang menggambarkan kondisi dari PT XYZ dan merubahnya dalam bentuk ProModel. Langkah selanjutnya setelah model selesai disusun, maka akan dilakukan pengambilan data dengan bantuan Microsoft Excel untuk membangkitkan angka acak dengan distribusi uniform. Data akan diuji 
kecukupannya dan bila tercukupi maka akan digunakan untuk simulasi di ProModel. Hasil simulasi akan di verifikasi dan akan dilakukan penyusunan model baru untuk penyusunan usulan perbaikan. Berdasarkan hasil yang ada, akan disusun suatu usulan model dengan penyusunan model konseptual, penyusunan simulasi di ProModel, pengambilan data dan pemasukan ke dalam ProModel, lalu melakukan verifikasi. Model usulan yang terverifikasi akan dilakukan uji $\mathrm{T}$ untuk membandingkan kondisi mana yang terbaik dan mengetahui signifikansi dari perubahan yang ada. Langkah terakhir adalah penyusunan kesimpulan dan saran setelah seluruh kondisi di uji $\mathrm{T}$ dan ditarik usulan terbaik.

\section{HASIL DAN DISKUSI}

\section{A. Kondisi Awal}

Model konseptual merupakan suatu kerangka kerja konseptual, sistem yang menerangkan tentang serangkaian ide global tentang keterlibatan individu, kelompok, situasi atau kejadian terhadap suatu ilmu dan pengembangannya. Model konseptual yang dibangun akan menampilkan realita, dengan rangkaian konsep yang akan dibangun dalam model simulasi. Pada simulasi akan menggunakan 7 lokasi dengan 8 entitas dan 8 resources atau sumber daya. Simulasi ini dilakukan dengan konsep make-to-demand. Dalam membuat satu telepon jadi, manufaktur membutuhkan satu bahan baku A, satu bahan baku B, dan juga satu box. Bahan baku A dan B akan diambil oleh perusahaan dari supplier A serta supplier B dan box packaging akan diambil dari supplier Box sehingga bill of material dari telepon ini tidak terlalu rumit. Perusahaan akan membeli bahan baku dari supplier dan menyimpannya di dalam gudang bahan baku sebanyak demand dari Toko. Lama waktu pengiriman bahan baku ini sendiri adalah 2 jam. Pengiriman menggunakan truk. Perusahaan memiliki titik pemesanan kembali sebanyak 50 untuk seluruh bahan baku, dan akan melakukan pemesanan kepada supplier sesuai ketentuan yang diberikan yaitu 1 container atau sebanyak 200 sekali kirim.

Seluruh bahan baku, baik itu box ataupun bahan baku telepon akan disimpan dalam satu gudang bahan baku dengan kapasitas sebesar 3.000 barang. Perusahaan akan melakukan produksi secara satu per satu. Proses produksi di lokasi Manufaktur (kapasitas 1.500) terdiri dari penggabungan dua bahan baku, yaitu A dan B serta box packaging. Lama waktu pembuatan telepon adalah 10 menit. Sedangkan untuk waktu perpindahan antar stasiun kerja adalah 40 detik, hanya perpindahan dari manufaktur ke GBJ yang memakan waktu 5 menit. Barang yang sudah jadi, akan dikirimkan ke gudang barang jadi. Kapasitas dari gudang barang jadi adalah infinity. Toko akan melakukan pemesanan telepon ke perusahaan sejumlah $\mathrm{T}$, dan apabila ada order yang masuk maka perusahaan akan mengirimkan barang tersebut dari gudang barang jadi menuju lokasi toko sejumlah $\mathrm{T}$ atau sejumlah demand yang dipesan. Lama waktu pengiriman dari gudang barang jadi kepada toko adalah 1 jam dengan menggunakan truk. Minimal pemesanan yang harus dilakukan oleh toko adalah 50 telepon $(\mathrm{T} \geq 50)$.

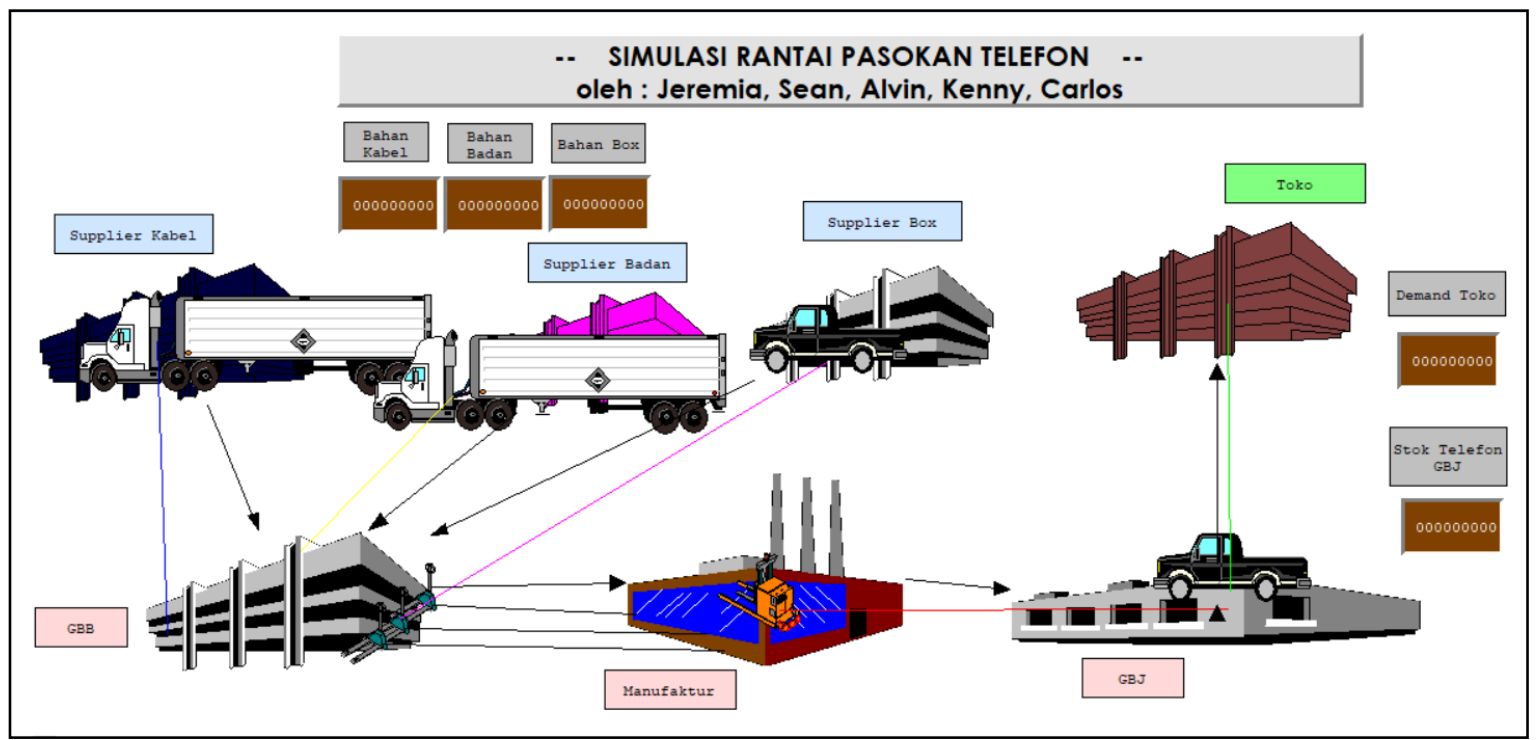

Gambar 2. Kondisi awal dalam simulasi ProModel 
Berdasarkan Gambar 2, akan dilakukan pemasukan data uniform yang mana sudah teruji kecukupannya dan akan dilakukan verifikasi dari model tersebut. Verifikasi dilakukan dengan cara menghitung apakah perhitungan manual untuk lama waktu pembuatan 50 telefon sama dengan perhitungan ProModel. Hasilnya, perhitungan manual mendapatkan total waktu sebesar 11 jam 30 menit, sedangkan ProModel mendapatkan hasil 11 jam 28 menit. Atas dasar ini, model dapat dikatakan terverifikasi. Setelah model kondisi awal terverifikasi, maka akan disusun suatu usulan perbaikan untuk mengoptimalkan rantai pasokan yang ada.

\section{B. Kondisi Usulan}

Terdapat sedikit perubahan pada model konseptual untuk kondisi usulan. terdapat beberapa perbedaan yang digunakan, agar model usulan berbeda dengan model awal. Pada model usulan pertama ini terdapat perbedaan pada waktu pembuatan atau waktu produksi pada manufaktur dipercepat selama 5 menit. Perubahan waktu dari wait 10 minutes pada model awal diubah menjadi wait 5 minutes. Hal ini bertujuan agar utilitas dari manufaktur meningkat dan membuat kinerja atau daya guna menjadi lebih tinggi. Kemudian diharapkan juga dengan percepatan ini membuat delay pada average time waiting pada entitas BahanBakuKabel, dapat berubah menjadi lebih rendah agar non-added value dapat berkurang. Perubahan yang dilakukan, dalam praktiknya bisa dilakukan dengan cara memperbaiki cara kerja dari pekerja di dalam manufaktur, lalu menyusun kembali rute produksi dengan baik dan meningkatkan kemampuan pekerja dengan memberikan beberapa pelatihan. Lalu juga dilakukan perubahan tentang waktu pengiriman forklift pada GBB, dimana jalur forklift untuk GBB diperbaiki pada kondisi nyata dengan mengatur ulang rute sehingga memakan waktu lebih cepat yaitu sekitar 20 detik. Perubahan terakhir juga dilakukan untuk pengiriman seluruh bahan baku dimana pada awalnya sebanyak 200 pcs untuk tiap bahan baku menjadi 400 pcs dan ROP dari 50 pcs menjadi 100 pcs. Hal ini ditambah mengingat perpindahan material yang jauh lebih cepat sehingga membuat stok menjadi lebih cepat untuk berkurang. Untuk keterangan lainnya mengikuti model awal sehingga hanya ada tiga perubahan, pertama yaitu perubahan waktu manufaktur dipercepat dengan merancang ulang proses manufaktur sehingga berubah dari 10 menit menjadi 5 menit dan perubahan. Kedua dilakukan perubahan waktu perjalanan forklift GBB dengan mengatur ulang rute dari forklift pada GBB sehingga berubah dari 40 detik menjadi 20 detik. Ketiga mengubah kuantitas pemesanan seluruh bahan baku dari 200 pcs menjadi 400 pcs dengan titik ROP dari 50 pcs menjadi 100 pcs.

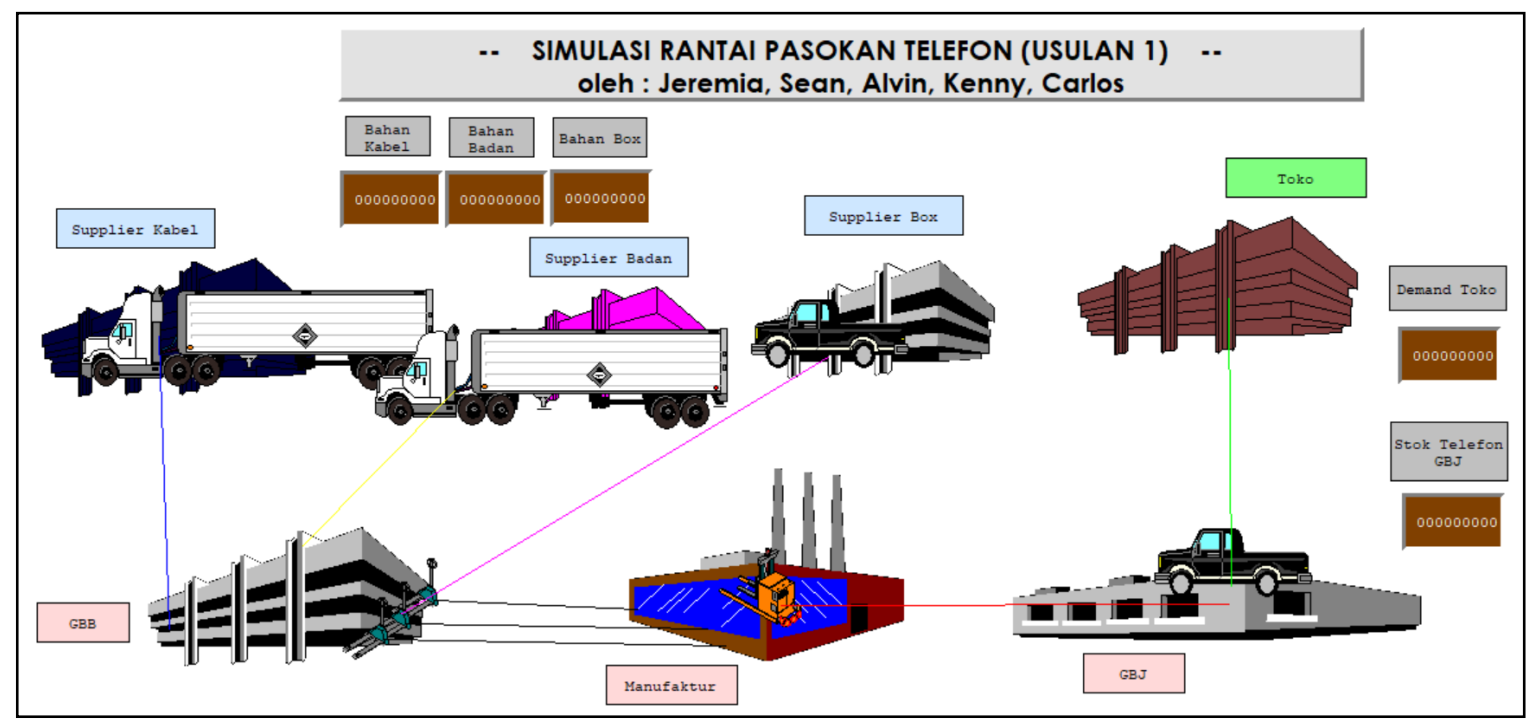

Gambar 3. Kondisi usulan dalam simulasi ProModel

Berdasarkan Gambar 3, akan dilakukan pemasukan data uniform yang mana sudah teruji kecukupannya dan akan dilakukan verifikasi dari model tersebut. Verifikasi dilakukan dengan cara menghitung apakah perhitungan manual untuk lama waktu pembuatan 50 telefon sama dengan perhitungan ProModel. Hasilnya, perhitungan manual mendapatkan total waktu sebesar 10 jam 34 menit, sedangkan ProModel mendapatkan hasil 10 jam 48 menit. Atas dasar ini, model dapat dikatakan terverifikasi. Setelah model kondisi awal terverifikasi, maka akan dilakukan perbandingan dengan menggunakan uji $\mathrm{T}$ dan hasil keluaran dari setiap model yang ada. 


\section{Perbandingan Antar Model}

Perbandingan model awal dengan model usulan pertama disini adalah membandingkan rata-rata lama waktu di dalam sistem. Perhitungan dilakukan dengan Uji T Dua Sampel dan akan membandingkan nilai $p$ value dengan alfa (5\%) maupun t-value dengan t-table untuk mengetahui signifikansi dari model usulan pertama dengan model awal. Uji T Dua Sampel dilakukan dengan menggunakan Minitab 2019.

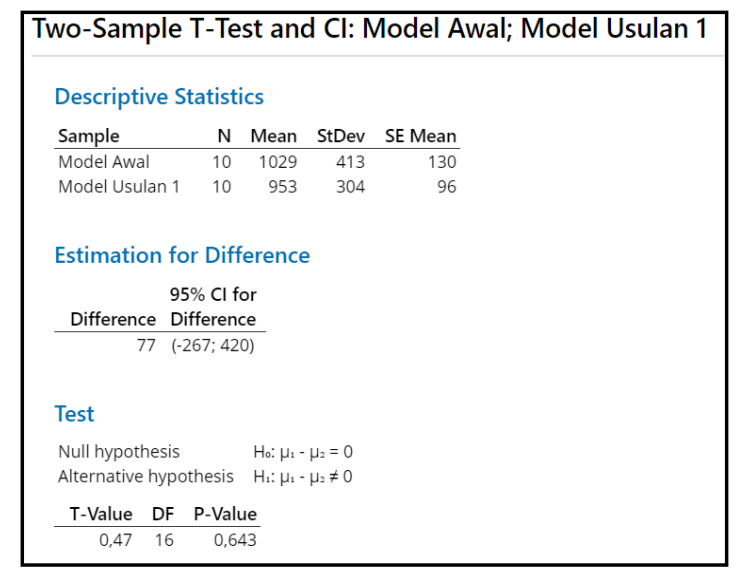

Gambar 4. Uji T dua sampel model awal dengan model usulan

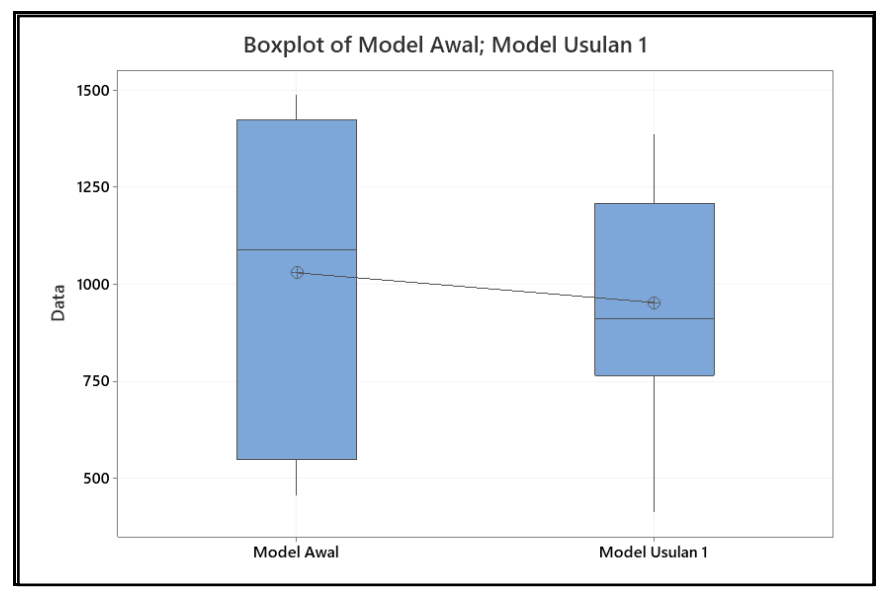

Gambar 5. Boxplot model awal dengan model usulan

Uji T ini menggunakan hipotesa yang mana $\mathrm{H}_{0}$ memiliki arti dimana nilai selisih antara dua mean $(\mu)$ bernilai 0 maka kedua model tersebut tidak berbeda secara signifikan. Sebaliknya $\mathrm{H}_{1}$ memiliki arti dimana nilai selisih antara dua mean $(\mu)$ tidak bernilai 0 maka kedua model tersebut berbeda secara signifikan. Pemilihan hipotesis yang benar akan menggunakan bantuan $p$-value. Nilai $p$-value yang lebih besar dari alfa (5\%) menandakan gagal tolak $\mathrm{H}_{0}$ atau terima $\mathrm{H}_{0}$, sebaliknya jika $p$-value lebih kecil dari alfa akan menandakan tolak $\mathrm{H}_{0}$ atau terima $\mathrm{H}_{1}$. Berdasarkan gambar 4 dapat dilihat bahwa $p$-value bernilai 0,643 dan lebih besar dari alfa, sehingga tidak ada perbedaan yang signifikan antara model awal dengan model usulan pertama dalam hal average waiting time in systems untuk BahanBakuKabel yang artinya, non-value added belum dapat dikurangi secara signifikan. Maka dari itu, terjadi penurunan antara model awal dengan model usulan pertama yang menandakan bahwa sebenarnya waktu menunggu yang menghasilkan non-value added untuk BahanBakuKabel sudah dapat diturunkan sesuai dengan garis penurunan pada gambar 5, namun penurunan ini tidak hanya penurunan dalam skala dan selisih yang kecil sehingga disebut tidak signifikan meskipun mampu menurunkan average waiting time in systems (non-value added) untuk BahanBakuKabel. 


\section{KESIMPULAN}

Model awal memiliki keunggulan dalam hal utilitas penggunaan forklift untuk GBB mengingat forklift adalah hal penting dalam rantai pasokan di dalam perusahaan, namun secara utilitas Manufaktur dan average time in system kurang baik bila dibandingkan dengan model usulan pertama. Perusahaan dapat mempertimbangkan antara memilih model awal dengan model usulan pertama apabila melihat beberapa poin. Jika perusahaan ingin berfokus untuk meningkatkan utilitas Manufaktur, utilitas GBJ, dan juga mengurangi non-added value untuk delay dari average time in system BahanBakuKabel, maka perusahaan dapat memilih model usulan pertama meskipun pengurangan waktu delay tidak signifikan. Namun meskipun tidak signifikan itu dapat menaikkan utilitas Manufaktur dari 52,53\% menjadi 77,46\%. Tetapi jika perusahaan ingin berfokus pada pengembangan dibagian lain, maka perusahaan tetap bisa mempertahankan model awal karena tidak berpengaruh secara signifikan, namun perusahaan tetap harus memperhatikan utilitas Manufaktur dan utilitas forklift GBB agar efisien. Perusahaan bisa mempertimbangkan untuk tetap mempertahankan model awal dengan model usulan, dengan tetap memperhatikan penggunaan forklift GBB dengan lebih efisien. Penggunaan forklift GBB yang efisien juga akan membantu perusahaan untuk menghemat biaya dan mengoptimalkan kinerja dari forklift itu sendiri, yang mana dampaknya akan meningkatkan utilitas Manufaktur dan forklift GBB, mengurangi non-value added time dalam BahanBakuKabel, dan membantu perusahaan mencapai tujuan dalam hal optimalisasi serta meraih lebih banyak demand yang berdampak pada peningkatan revenue dari perusahaan sehingga mampu mencapai skala ekonomis.

\section{DAFTAR PUSTAKA}

Cornellia, R. (2018). Analisis antrian pada loket pembuatan elektronik KTP dengan menggunakan simulasi promodel. Jurnal String, 3(2), 119-129

Hamali, S. (2017). Simulasi. Binus Business School. https://bbs.binus.ac.id/management/2017/11/simulasi/

Heinser, J., Render, B., \& Munson, C. (2017). Operations management: Sustainability and Supply Chain Management (12th ed.). Essex: Pearson

Lukmana, T., \& Trivena, D. (2015). Penerapan metode EOQ dan ROP (Studi kasus: PD. Baru). Jurnal Teknik Informatika dan Sistem Informasi, 1(3), 271-279

Munirah, M., \& Subanar, S. (2017). Kajian terhadap beberapa metode optimasi (Survey of optimization methods). Jurnal JUITA, 5(1), 45-50

Riswana, S. A. (2018). Pemodelan ulang instalasi sistem perpipaan dengan software autocad plant 3D versi 2018 [Undergraduate thesis, Universitas Muhammadiyah Yogyakarta]. Repository Universitas Muhammadiyah Yogyakarta

Soeprajogo, M. P., \& Ratnaningsih, N. (2020). Perbandingan dua rata-rata uji-T. Perpustakaan Pusat Mata Nasional Rumah Sakit Mata Cicendo. http://perpustakaanrsmcicendo.com/2020/07/02/perbandingandua-rata-rata-uji-t/

Sugiarto, F., \& Buliali, J.L. (2012). Implementasi simulasi sistem untuk optimasi proses produksi pada perusahaan pengalengan ikan. Jurnal Teknik ITS, 1(1), 236-241

Trenggonowati, D. L. (2017). Optimasi proses produksi dengan menggunakan pendekatan simulasi system. Jurnal PASTI: Penelitian dan Aplikasi Sistem \& Teknik Industri, 11(1), 1-12

Unsulangi, H., Jan, A., \& Tumewu, F. (2019). Analisis Economic Order Quantity (EOQ) pengendalian persediaan bahan baku kopi pada PT. Fortuna Inti Alam. Jurnal EMBA: Jurnal Riset Ekonomi, Manajemen, Bisnis, dan Akuntansi, 7(1), 51-60 